\title{
Chemical Characterization and Anti-Radical Activity of Fruits and Vegetables Commonly Consumed in Brazzaville
}

\author{
Gouollaly Tsiba',2, Josiane Enzonga Yoca ${ }^{3}$, Mboungou-Bouesse Blondy ${ }^{1}$, \\ Andzi-Barhe Thimoleon ${ }^{4}$, et Pascal Ongoka ${ }^{4}$
}

\begin{abstract}
${ }^{1}$ Institut National de Recherche en Sciences de la Santé (IRSSA), Département de la Pharmacopée et Médecine Traditionnelle, Laboratoire de Chimie des Biomolécules organiques et de Pharmacodynamie. Cité Scientifique (Ex-ORSTOM), Brazzaville, Congo ${ }^{2}$ Université Marien Ngouabi-Faculté des Sciences et Techniques, Parcours Chimie, Brazzaville, Congo

${ }^{3}$ Laboratoire de Contrôle et Qualité des aliments de l'Ecole Nationale Supérieure d'Agronomie et de Foresterie, Université Marien NGOUABI, Brazzaville, Congo

${ }^{4}$ Université Marien Ngouabi-Ecole Normale Supérieure-Parcours Sciences Exactes, Brazzaville, Congo

Email: josiane0204@yahoo.fr
\end{abstract}

How to cite this paper: Tsiba, G., Yoca, J.E., Blondy, M.-B., Thimoleon, A.-B. and Ongoka, E.P. (2020) Chemical Characterization and Anti-Radical Activity of Fruits and Vegetables Commonly Consumed in Brazzaville. Food and Nutrition Sciences, 11, 773-788.

https://doi.org/10.4236/fns.2020.118055

Received: July 18, 2020

Accepted: August 15, 2020

Published: August 18, 2020

Copyright $\odot 2020$ by author(s) and Scientific Research Publishing Inc. This work is licensed under the Creative Commons Attribution International License (CC BY 4.0).

http://creativecommons.org/licenses/by/4.0/

\begin{abstract}
The objective of this study was to analyze ten (10) species of edible vegetables and nine (9) fruit commonly found in Congo (Brazzaville) in order to determine their total polyphenol content (TPC) and total flavonoid content (TFC), and their antiradical activity by the method of 1,1-diphenyl-2-picrylhydrazyl (DPPH). The results obtained showed that the highest TPC and TFC were found, on the one hand, in the extracts of four species of vegetables, i.e. Ipomoea batatas L. (536.02 $\pm 0.01 \mathrm{mg}$ of GAE/100 g DW; $486.46 \pm 0.10 \mathrm{mg}$ of QtE/100 g DW), Cucurbita pepo (533.60 $\pm 0.05 \mathrm{mg}$ of GAE/100 g DW; 303.72 $\pm 0 \mathrm{mg}$ of $\mathrm{QtE} / 100 \mathrm{~g} \mathrm{DW})$, Hibiscus sabdariffa $(421.02 \pm 0.015 \mathrm{mg}$ of GAE/100 g DW; $243.49 \pm 0.10 \mathrm{mg}$ of QtE/100 g DW), Solanum negrum 1 $(412.10 \pm 0.05 \mathrm{mg}$ of GAE/100 g DW; $292.10 \pm 0.14 \mathrm{mg}$ of QtE/100 g of DW) and, on the other hand, in the extracts of two species of fruit, i.e. Chrysophyllum lacourtianum $(532.79 \pm 0.19 \mathrm{mg}$ of GAE/100 g of DW; $380.55 \pm 0.10$ $\mathrm{mg}$ of QtE/100 $\mathrm{g}$ of DW) and seeds of Aframomum alboviolaceum (469.38 \pm $0.28 \mathrm{mg}$ of GAE/100 g DW; $107.27 \pm 0.10 \mathrm{mg}$ of QtE/100 g DW). The lowest TPC and TFC were obtained with the extracts of Brassica campestris and of Spinacia oleracea, respectively $97.78 \pm 0.17 \mathrm{GAE} \mathrm{mg} / 100 \mathrm{~g}$ DW and $27.52 \pm$ $0.10 \mathrm{QtE} \mathrm{mg} / 100 \mathrm{~g} \mathrm{DW}$. The extract of the Saba senegalensis pulp had the lowest TPC and TFC. In addition, the highest antiradical activity was observed with extracts from vegetables and fruit with high TPC and TFC. The results indicate that these vegetables and fruit could be potential sources of the phenolic compounds and the biomolecules having several biological ac-
\end{abstract}


tivities. Thus, their consumption might be an alternative in the prevention of chronic diseases.

\section{Keywords}

Fruit, Vegetables, Polyphenols, Flavonoid, Antiradical Activity

\section{Introduction}

Food and dietary habits play an important role in the prevention of chronic diseases. Fruit and vegetables are undoubtedly crucial for a healthy diet and balanced. The diets rich in fruit and vegetables are also related to a reduction of the risk of diseases [1] [2]. The consumption of a $400-600 \mathrm{~g}$ portion of fruit and vegetables per day is recommended by World Health Organization (WHO), Food and Agriculture Organization (FAO) and the World Cancer Research Fund [3] [4] [5] [6], and it can reduce the global burden of disease [7].

Epidemiological investigations of previous studies [8] [9] [10], have shown that diets rich in fruit and vegetables have beneficial effects against common chronic diseases caused by oxidative stress such as cancer, obesity, cardiovascular and neurodegenerative diseases. The health benefits of fruit and vegetables have been partially attributed to their phenolic compounds, which have received particular attention due to their antioxidant properties [11] [12]. In effect, fruit and vegetables are a true important source bioactive substance including polyphenolics of polyphenolic compounds and provide desirable benefits for animal health beyond basic nutrition [13] [14] [15] [16]. Dietary polyphenol intakes from fruit and vegetables are well known to lower the risk of several oxidative stresses including cardiovascular diseases, cancer, stroke and coronary heart [17] [18].

These polyphenolic compounds have a wide range of biological activities in vitro, including anti-allergic, anti-atherogenic, anti-inflammatory, anti-microbial, anti-thrombotic, cardioprotective and vasodilatory actions, related of their hydrogen and electron donating abilities and metal chelating effects [2]. In addition, owing to the presence of the conjugated ring structures and hydroxyl groups, several phenolic compounds can potentially function as antioxidants by scavenging superoxide anion, singlet oxygen and lipid peroxyl radicals by stabilizing free radicals involved in oxidation processes through or combining with oxidizing species [19].

The antioxidant properties of these compounds allow them to inhibit the oxidation in both the dietary (oxidation of lipoproteins) and physiological (oxidative stress) fields [20]. They are capable of preventing the oxidation of Low Density Lipoproteins (LDL) and could thereby protect the organism against myocardial infarction or coronary atherosclerosis, which are associated high levels cholesterol of level LDL circulating in the blood [21], and to reduce free radicals that are often the cause of the oxidative stress [22]. These substances are of great in- 
terest in several areas, including nutrition by their preventive nature with regard to various diseases as mentioned above, cosmetology and especially the food industry through their implication, in particular, on the flavor of food and their impact on the preservation of food products [23] [24]. Thus, fruit and vegetables containing them could constitute an alternative to the use of synthetic food additives which have shown harmful effects [25]. In view of these advantages, the consumption of fruit and vegetables should be encouraged to curb these chronic pathologies. However, their consumption is very low worldwide, with the lowest consumption reported in Sub-Saharan Africa [6]. Low fruit and vegetable consumption are synonymous with an unbalanced and unhealthy diet, which can be linked to various diseases and in the worst cases associated with increased mortality rates. The poverty is one of the main factors contributing to low fruit and vegetable consumption in developing countries, and this is also the case in the Republic of Congo. However, Sub-Saharan Africa in general, and the Republic of the Congo in particular, is endowed with several endemic species of fruit and vegetables that could be exploited in the diet and help solve some problems related to chronic diseases. Despite these advantages, very few studies on their characterization as bioactive compounds, especially polyphenols, have been carried out up to now.

It is with this in mind that we were interested in nine (9) fruit, i.e. Annona muricata L, Citrus reticulata L, Aframomum giganteum, Saba senegalensis, Anisophyllea quangensis Engl. Ex henriq, Chrysophyllum lacourtianum, Passiflora quadrangularis, Aframomum alboviolaceum et Ficus capensis Thumb and ten (10) vegetables: Ipomoea batatas L, Spinacia oleracea, Hibiscus sabdariffa, Amaranthus, Solanum nigrum (1), Dioscorea liebrechtsiana De Wild, Solanum melongena L, Cucurbita pepo L, Brassica campestris L, Solanum nigrum (2), commonly consumed in Brazzaville so as to measure the quantitative potential of total polyphenols, and then evaluate subsequently the antioxidant power of the various hydro-ethanol extracts of these fruit and vegetables.

\section{Materials and Methods}

\subsection{Plant Material}

The plant material for this study consists of the fruit and vegetables, presented in Table 1 and Table 2, which were, on the one hand, harvested in the "ex-Tele zone" in the first district Makélékélé of Brazzaville and, on the other hand, purchased at the "Total market" in the second district and the "Lycée Thomas Sankara market" in the ninth district of Brazzaville. The different plants were identified by Dr. Jean Marie MOUTSAMBOTE from the National Institute for Research in Exact and Natural Sciences (IRENS) of Brazzaville (Congo).

\subsection{Reagents}

2,2-diphenyl-1-picrylhydrazyl (DPPH), Quercetin and Folin-Ciocalteu were purchased from Sigma Aldrich. Gallic acid was obtained from Merck. 
Table 1. The different vegetables used for analyses.

\begin{tabular}{|c|c|c|c|}
\hline Systematic names & Pictures of vegetables & Popular names & Organs used \\
\hline Ipomoea batatas $\mathrm{L}$. & & Matembelé & leaves \\
\hline Spinacia oleracea & & Spinach & leaves \\
\hline Hibiscus sabdariffa & & Oseille & leaves \\
\hline Amaranthus & & Bary & leaves \\
\hline Solanum nigrum 1 & & Moussosso 1 & leaves \\
\hline $\begin{array}{c}\text { Dioscorea liebrechtsiana } \\
\text { De Wild }\end{array}$ & & Ntinia & seedling \\
\hline Solanum melongena $L$ & & Eggplant & Fruit \\
\hline Cucurbita pepo L & & Ngapara & leaves \\
\hline Brassica campestris $L$ & & Loundif & leaves \\
\hline Solanum nigrum 2 & & Moussosso 2 & leaves \\
\hline
\end{tabular}


Table 2. The different fruit used for analyses.

\begin{tabular}{|c|c|c|c|}
\hline Systematic names & Pictures of vegetables & Popular names & Organs used \\
\hline Annona muricata $L$ & & Corossol & Pulp \\
\hline Citrus reticulata $L$ & & Mandarin & Pulp \\
\hline $\begin{array}{l}\text { Aframomum } \\
\text { giganteum }\end{array}$ & & Tondolo 1 & Pulp and seeds \\
\hline Saba senegalensis & & Malombo & Pulp \\
\hline $\begin{array}{c}\text { Anisophyllea } \\
\text { quangensis Engl. Ex } \\
\text { henriq }\end{array}$ & & Bila Esobé & Pulp \\
\hline $\begin{array}{l}\text { Chrysophyllum } \\
\text { lacourtianum }\end{array}$ & & Bamou & Pulp \\
\hline $\begin{array}{c}\text { Passiflora } \\
\text { quadrangularis }\end{array}$ & & Barbadine & Pulp \\
\hline $\begin{array}{l}\text { Aframomum } \\
\text { alboviolaceum }\end{array}$ & & Tondolo 2 & Pulp and seeds \\
\hline
\end{tabular}




\subsection{Sample Processing}

The different fruit and vegetables collected were carefully washed with tap water and the organs used were: pulp and seeds for fruit, leaves and seedling for vegetables. The organs of the different fruit were then dried in an oven at $40^{\circ} \mathrm{C}$ and those of the vegetables at room temperature away from light for 7 days until their mass had stabilized. The dried organs were crushed and the powder obtained was stored before the various analyses.

\subsection{Preparation of the Different Extracts}

The extracts for determining of total polyphenols and flavonoids, and antiradical activities were obtained by mixing $30 \mathrm{~g}$ of the plant material in $2 \times 150 \mathrm{~mL}$ of the hydro-ethanol solution of a $50 \%(\mathrm{v} / \mathrm{v})$. The mixture was stirred for 72 hours, and then filtered. The filtrate obtained was concentrated dry from a rotary evaporator and stored in a cold place $\left(+4^{\circ} \mathrm{C}\right)$ awaiting analysis [25].

\subsection{Determination of the Total-Polyphenol Content}

The determination of total polyphenol content (TPC) was carried out using Folin-Ciocalteu colorimetric method described by Muanda et al. [26]. This quantitative assay was performed by mixing in an Eppendorff tube $0.1 \mathrm{~mL}$ of the hydroethanolic extract $(2 \mathrm{mg} / \mathrm{mL}), 0.9 \mathrm{~mL}$ of distilled water and $0.9 \mathrm{~mL}$ of the Folin-Ciocalteu reagent $(1 \mathrm{~N})$, and then immediately following $0.2 \mathrm{~mL}$ of a $20 \%$ sodium carbonate $\left(\mathrm{Na}_{2} \mathrm{CO}_{3}\right)$ was added. The absorbance of the obtained mixture was measured at $760 \mathrm{~nm}$ employing a spectrophotometer after incubation for $40 \mathrm{~min}$ at room temperature in the dark against a methanol solution used as a blank. Quantification was conducted on the basis of a standard curve of gallic acid analyzed under the same conditions as the samples. Results are expressed as milligrams of gallic acid equivalent (GAE) per 100 grams of dry weight (GAE/100 g DW).

\subsection{Determination of Total Flavonoid Content}

The total flavonoid content (TFC) was determined using the colorimetric method described by Muanda et al. [26]. For this purpose, $250 \mu \mathrm{L}$ of the hydro-ethanol extract and $1 \mathrm{~mL}$ of water were introduced successively into a 10 $\mathrm{mL}$ flask. At the initial time ( 0 minutes), $75 \mu \mathrm{L}$ of a $5 \%$ sodium nitrite solution was added. After 5 minutes, $75 \mu \mathrm{L}$ of a $10 \%$ aluminium trichloride solution was added. At $6 \mathrm{~min}, 500 \mu \mathrm{L}$ of sodium hydroxide $(1 \mathrm{~N})$ was added to the mixture. Immediately, $2.5 \mathrm{~mL}$ of distilled water was added to the mixture. The absorbance of the mixture obtained was measured at $510 \mathrm{~nm}$ with the UV-visible spectrophotometer. A calibration curve was drawn up using standard solutions of quercetin prepared at different concentrations. The TFC was calculated and expressed as a quercetin equivalent [milligrams of quercetin equivalent $(\mathrm{QtE})$ per 100 grams of dry weight (QtE/100 g DW)]. 


\subsection{Evaluation of Anti-Radical Activity}

The DPPH radical scavenging activity was determined using the method described by Hennebelle [27] The test solution was performed by mixing $10 \mathrm{~mL}$ of a $10 \mathrm{mg} / 250 \mathrm{ml}$ of 2,2-diphenyl-1-picrylhydrazyl (DPPH) solution with $100 \mu \mathrm{L}$ of the test extract at different concentrations ( 5 to $50 \mathrm{mg} / \mathrm{mL}$ ). The activity was then measured at $517 \mathrm{~nm}$ employing a spectrophotometer UV-visible after a 30 minute-incubation in the dark. The percentage of inhibition of DPPH was calculated by the following relationship:

$$
\% \text { inhibition }=\frac{(\text { ABlank }- \text { ASample })}{(\text { ABlank })} \times 100
$$

ABlank: Absorbance of Blank; ASample: Absorbance of sample.

The IC50 was determined by evaluating the free radical scavenging activity of several dilutions of each sample and interpolating the extract concentration whose inhibition percentage reached $50 \%$. The IC50 value was calculated from the graph plotting the scanning activity for the selected fruits and vegetables.

\subsection{Statistical Analysis}

All tests were performed in triplicate. The statistical analyses were carried out with $\mathrm{R}$ software version 3.3.3. The Pearson's Chi-squared test was used to compare two by two the measured parameters (TPC, IC50 and TFC) of fruit and vegetables. All tests had a significance level of 5\%.

\section{Results and Discussion}

\subsection{Total Polyphenol Content (TPC) of Different Extracts of Vegetables}

The regression equation from calibration curve of galic acid was of $\mathrm{Y}=3.9089 \mathrm{x}$ +0.1257 , with a correlation coefficient: $\mathrm{R}^{2}=0.9989$. The TPC expressed in mg GAE/100 g DW are shown in Figure 1. These results show that TPC vary in different vegetable extracts.

In Figure 1, we can see that the highest TPC values were found in the extracts of I. batatas and C. pepo, which were respectively $536.02 \pm 0.01$ and $533.60 \pm 0.05$ $\mathrm{mg}$ of GAE/100 g DW, and they are statistically identical $(\mathrm{P}>0.05)$. Followed of the extracts of $H$. sabdariffa $(421.02 \pm 0.015 \mathrm{mg}$ of GAE/g DW) and $S$. negrum 1 $(412.10 \pm 0.05 \mathrm{mg}$ of GAE/g DW), that are also statistically identical $(>0.05)$. Ours values were generally higher than the ones reported by Yadav et al. [15], especially in methanolic, ethanolic and butanolic extracts of C. pepo which were respectively $519.81 \pm 2.35,336.25 \pm 1.52$ and $272.01 \pm 1.57 \mathrm{mg}$ of GAE/100 g $\mathrm{DW}$, and in the ethanol extracts of six other varieties of gourd leaves, i.e. Cucurbita maxima (56.11 $\pm 0.69 \mathrm{mg}$ of GAE/100 g DW), Trichosanthes dioica (118.82 $\pm 1.11 \mathrm{mg}$ of GAE/100 g DW), Luffa acutangula (156.23 $\pm 2.02 \mathrm{mg}$ of GAE/100 g DW), Lageneria siceraria (463.64 $\pm 1.37 \mathrm{mg}$ of GAE/100 g DW), Momordica. charantia (440.79 $\pm 2.12 \mathrm{mg}$ of GAE/100 g DW) and Lageneria cylindrica (300.06 $\pm 2.51 \mathrm{mg}$ of GAE/100 g DW). Extracts of Amanranthus (194.79 \pm 0.03 


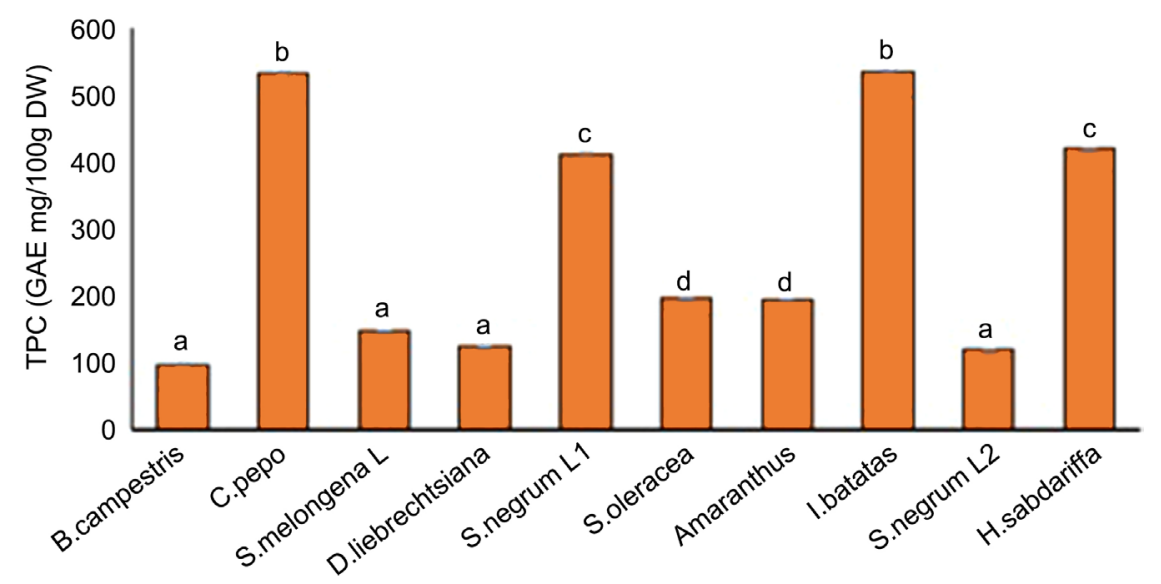

Figure 1. Total Polyphenol Content (TPC) of different hydro-ethanol extracts from studied vegetables. When the letters above the bars are identical, the averages are identical (at the 5\% threshold). Otherwise, the averages are significantly different (at the $5 \%$ threshold).

$\mathrm{mg}$ of GAE/100 $\mathrm{g} \mathrm{DW}$ ) and $S$. oleacea (196.79 $\pm 0.03 \mathrm{mg}$ of GAE/100 $\mathrm{g} \mathrm{DW})$ had mean TPC that were statically identical $(\mathrm{P}>0.05)$, while those of $S$. negrum 2 $(120.09 \pm 0.03 \mathrm{mg}$ of GAE/100 g DW), S. melongena $(147.30 \pm 0.11 \mathrm{mg}$ of GAE/g DW), B. campestris (97.78 $\pm 0.17 \mathrm{mg}$ of GAE/100 g DW) and D. liebrechtsiana De Wild $(124.7 \pm 0.01 \mathrm{mg}$ of GAE/100 g DW) had relatively low TPC and did not show significant differences $(\mathrm{P}>0.05)$.

\subsection{Total Polyphenol Content (TPC) of Different Extracts of Fruit}

Results showing the total polyphenol contents (TPC) determined in the hydroethanolic extracts of edible fruits are presented in Figure 2. Regarding this Figure, the extract TPC of $C$. lacourtianum (532.79 $\pm 0.19 \mathrm{mg}$ of GAE/100 g DW) and the seeds of $A$. alboviolaceum $(469.38 \pm 0.28 \mathrm{mg}$ of GAE/100 g DW) were much higher than those of any other fruit under study. However, the extract of $C$. lacourtianum showed significantly $(\mathrm{P}<0.05)$ higher value of TPC than the one of A. alboviolaceum. It should be noted that those values were considerably higher than the ones of Ficus carica (331.93 $\pm 51.19 \mathrm{mg} / 100 \mathrm{~g} \mathrm{MS})$, Prunus armenidca (304.63 $\pm 38.84 \mathrm{mg} / 100 \mathrm{~g}$ MS), Phoenix dactylifera $(241.61 \pm 50.48 \mathrm{mg} / 100 \mathrm{~g}$ MS) and Prunus amygdalus (109.07 $\pm 15.96 \mathrm{mg} / 100 \mathrm{gMS}$ ) dry fruit of commonly consumed in India reported by Vijaya Kumar Reddy et al. [14], and similar to those found in fruit regularly consumed in the Malaysia such as Baccaurea polyneura (546.25 $\pm 15.70 \mathrm{mg}$ of GAE/100 g), Mangifera odorata (487.00 $\pm 8.23 \mathrm{mg}$ of GAE/100 g) and Syzygium jambos (555.57 $\pm 28.33 \mathrm{mg}$ of GAE/100 g) published by Ikram et al. [28], and to other dried fruit consumed in Algeria, such as apricots and figs, with values of $630 \mathrm{mg} \mathrm{GAE} / 100 \mathrm{~g}$ DW and $520 \mathrm{mg}$ GAE/100 g DW, respectively [29].

In addition, we noted not negligible TPC in extracts of $C$. reticulata, $P$. quadrangularis and $A$. alboviolaceum $(\mathrm{P}+\mathrm{S})$, with values $186.89 \pm 0.05,106.12 \pm 0.07$ and $93.23 \pm 0.11 \mathrm{mg}$ of GAE/100 $\mathrm{g} \mathrm{DW}$, respectively. The value for $C$. reticulata is 


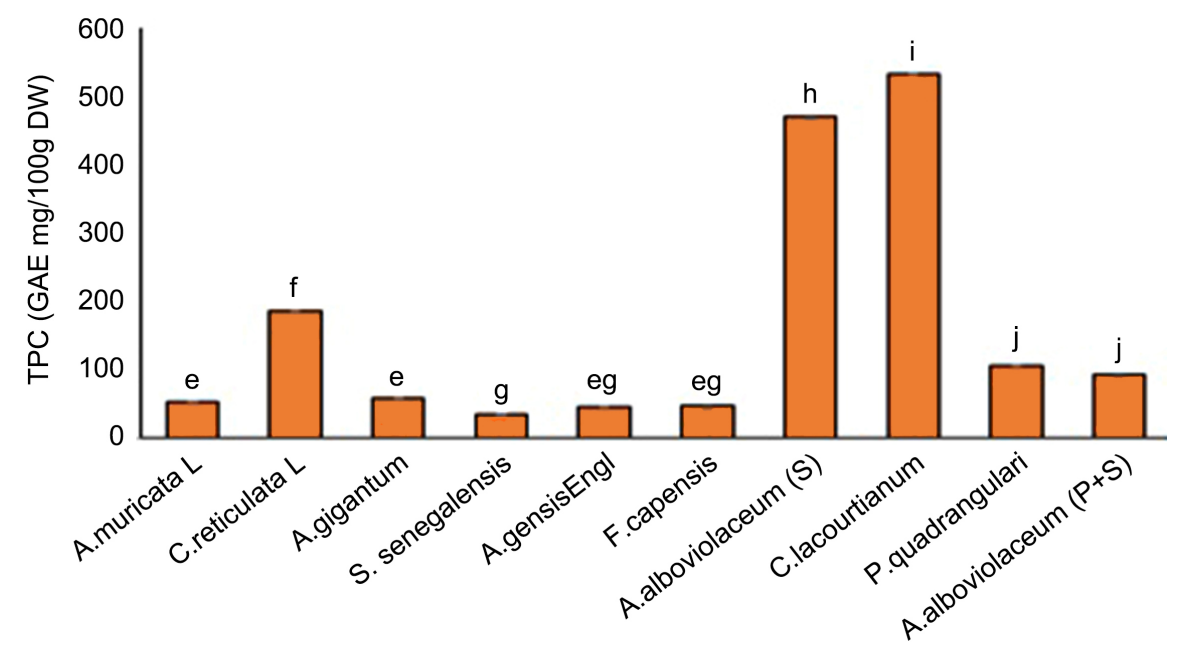

Figure 2. Total Polyphenol Content of different hydro-ethanol extracts from studied fruit. $\mathrm{S}=$ seeds, $\mathrm{P}=$ pulp. When the letters above the bars are identical, the averages are identical (at the $5 \%$ threshold). Otherwise, the averages are significantly different (at the $5 \%$ threshold).

statistically different from two other extracts $(\mathrm{P}$-value $<0.05)$, which are statistically identical (P-value $>0.05$ ).

The low TPC were obtained with extracts of $A$. muricata $(54.24 \pm 0.13 \mathrm{mg}$ GAE/100 g DW), A. gigantum pulp and seed (59.65 $\pm 0.09 \mathrm{mg} \mathrm{GAE} / 100 \mathrm{~g} \mathrm{DW})$, S. senegalensis ( $35.46 \pm 0.15 \mathrm{mg}$ GAE/100 g DW), A. gensisEngl (46.75 $\pm 0.2 \mathrm{mg}$ GAE/100 g DW) and F. capensis (47.56 $\pm 0.15 \mathrm{mg} \mathrm{GAE} / 100 \mathrm{~g} \mathrm{DW})$. We observed a significant variation $(\mathrm{P}<0.05)$ between the mean of $S$. senegalensis and those of $A$. muricata and $A$. gigantum, which are statistically identical (P-value $>$ 0.05) to the ones of $A$. gensisEngl and F. capensis. In addition, the TPC value of S. senegalensis pulp is very low compared to that obtained by Lamien-Meda et al. [7] on the acetone $(872.33 \mathrm{mg} \mathrm{GAE} / 100 \mathrm{~g}$ ) and methanol $(505.83 \mathrm{mg}$ GAE/100 g) extracts from the same fruit. This difference could be explained by the climate as well as the extraction solvent used.

\subsection{Total Flavonids Content (TFC) of Different Extracts of Vegetables}

The regression equation from calibration curve of quercetin was of $\mathrm{Y}=1.6954 \mathrm{x}$ +0.2816 , with a correlation coefficient: $\mathrm{R}^{2}=0.9955$. The TFC of the extracts of the different vegetables expressed in $\mathrm{mg}$ QtE/100 g DW are presented in Figure 3.

In this figure, we observe that the extract of $I$. batatas $(486.46 \pm 0.10 \mathrm{mg}$ of $\mathrm{QtE} / 100 \mathrm{~g}$ DW) had a far $(\mathrm{P}<0.05)$ higher TFC than the other extracts. Followed by C. pepo (303.72 $\pm 0.10 \mathrm{mg}$ of QtE/100 g DW) and S. negrum 1 (292.10 $\pm 0.14 \mathrm{mg}$ of QtE/100 g DW) extracts, and finally $H$. sabdariffa $(243.49 \pm 0.10$ $\mathrm{mg}$ of $\mathrm{QtE} / 100 \mathrm{~g} \mathrm{DW}$ ). The extracts of $S$. melongena $L$, D. liebrechtsiana De Wild, Amaranthus, $S$. nigrum L2, B. campestris and $S$. oleracea presented the lowest TFC, with values of $95.08 \pm 0.04 ; 74.24 \pm 0.12 ; 59.70 \pm 0.10 ; 52.43 \pm 0.20$; 


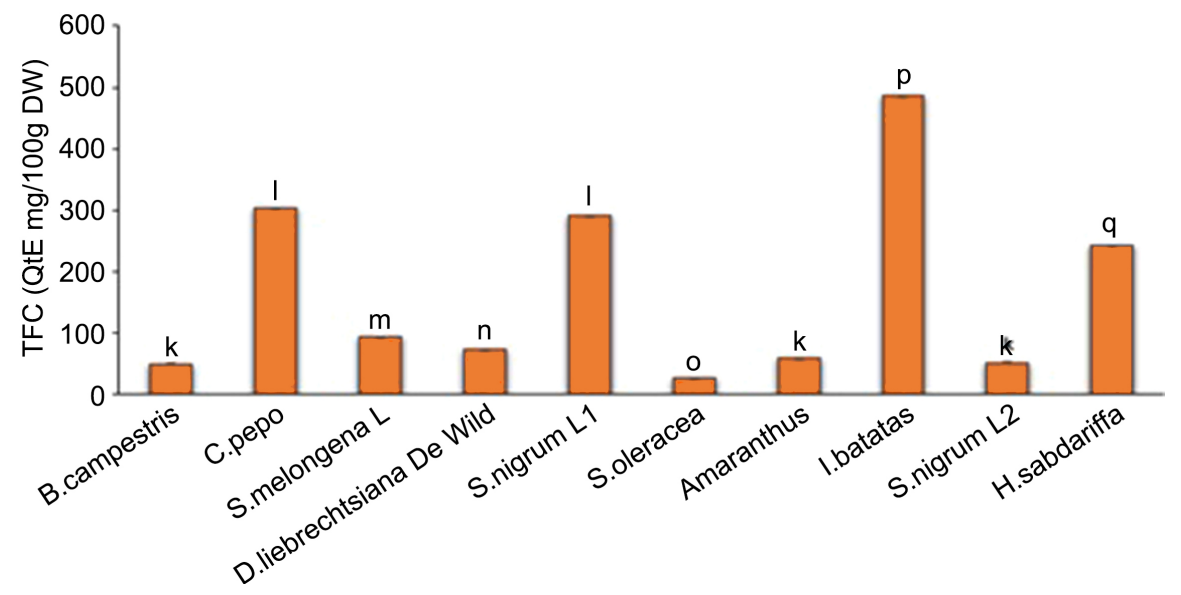

Figure 3. Total Flavonoid Content (TFC) of different hydro-ethanol extracts from vegetables. When the letters above the bars are identical, the averages are identical (at the 5\% threshold). Otherwise, the averages are significantly different (at the 5\% threshold).

$50.36 \pm 0.10$ and $27.52 \pm 0.10 \mathrm{mg}$ of QtE/100 g DW, respectively. Nevertheless, our values were higher than or similar to the ones found by Yadav et al. [15] on the ethanol extracts of seven varieties of squash with values between $3.73 \pm 0.22$ and $84.85 \pm 0.35 \mathrm{mg}$ of QtE/100 g DW.

\subsection{Total Flavonoid Content (TFC) of Different Hydro-Ethanol Extracts from Fruit}

The results were expressed as quercetin equivalents using the regression equation from the standard curve of quercetin, $Y=1.6954 x+0.2816 ; R^{2}=0.9955$. Figure 4, presenting the TFC results of the extracts of the different selected fruit, shows that the highest TFC was observed in the extract of $C$. lacourtianum $(380.55 \pm 0.10 \mathrm{mg}$ of QtE/100 g DW), with significant variations (P-value $<0.05$ ) than the other fruit, followed of the extract of $A$. alboviolaceum seeds $(107.27 \pm 0.10 \mathrm{mg}$ of QtE/100 $\mathrm{g}$ DW). Extracts from $C$. reticulata $L(64.89 \pm 0.03 \mathrm{mg} \mathrm{EQt} / 100 \mathrm{~g} \mathrm{DM})$ and $P$. quadrangularis $(59.70 \pm 0.01 \mathrm{mg}$ EQt/100 g DM) revealed low TFCs which were significantly different $(P<0.05)$, with non-significant variations $(P>0.05)$. In addition, lowest TFC values with not significant variations $(\mathrm{P}>0.05)$ were recorded for A. gigantum, A. muricata L, A. gensisEngl, A. alboviolaceum $(\mathrm{P}+\mathrm{S}), F$. capensis and $S$. senegalensis, with values of $36.86 \pm 0.03 ; 34.78 \pm 0.05 ; 31.70 \pm 0.03 ; 31.67 \pm$ $0.01 ; 28.55 \pm 0.1$ and $23.36 \pm 0 \mathrm{mg}$ of QtE/100 g DW, respectively. When comparing with the work by Benmeddour et al. [30] on the TFCs of ten Algerian date cultivars, this study showed that, exception the C. lacourtianum fruit which had a high value, the other fruit presented TFC values within the value range of those ten date varieties (15.22 to $299.74 \mathrm{mg} \mathrm{QE} / 100 \mathrm{~g} \mathrm{DW}$ ).

These results direct us towards the regular consumption of vegetables such as I. batatas, C. pepo, H. sabdariffa and $S$. negrum 1, and fruit such as A. alboviolaceum and $C$. lacourtianum, which are rich in total polypenolic compounds and total flavonoid. These fruit and vegetables could help to avoid disorders related to oxidative stress such as degenerative diseases [31], and provide protection 


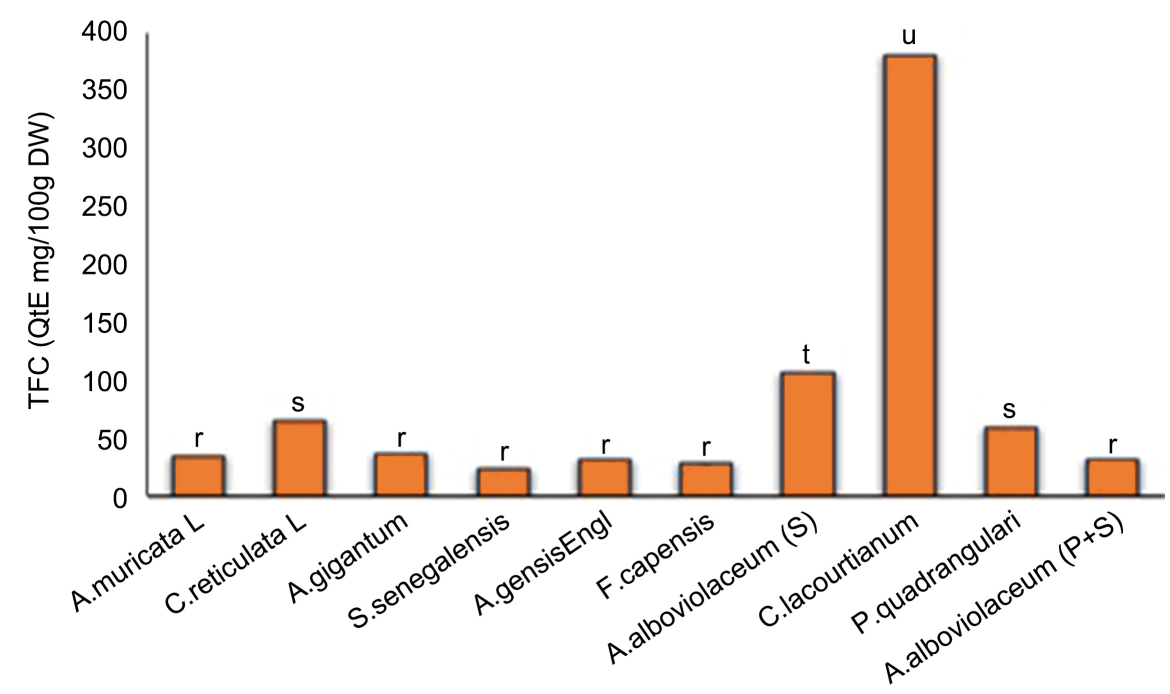

Figure 4. Total Flavonoid Content (TFC) of different hydro-ethanol extracts from fruit. S $=$ seeds, $\mathrm{P}=$ pulp. When the letters above the bars are identical, the averages are identical (at the $5 \%$ threshold). Otherwise, the averages are significantly different (at the 5\% threshold).

against oxidation at the cellular level by interfering in enzyme activity, chelation of redox active metals and free radical scavenging [32]. Dietary polyphenols may provide indirect protection by activating endogenous defence systems and modulating cell signaling processes such as NF- $\mathrm{KB}$ activation, AP-1 DNA binding, glutathione biosynthesis and various biochemical processes involved in the activation of carcinogenesis [33] [34]. In addition, phenolic compounds such as flavonoids are powerful free radical scavengers in fruit and vegetables. They protect lipids and vital cells from oxidative damage, participate in the prevention of coronary heart disease, and have antiproliferative or anticancer activities [35] [36] [37].

\subsection{Evaluation of the Antiradical Activity of the Different Extracts Vegetables}

The results of the anti-radical activity of extracts from vegetables are presented in Figure 5.

From the analysis of Figure 5, it appears that extracts of S. nigrum L1, $H$. sabdariffa, I. batatas, S. oleracea and C. pepo better inhibit free radicals with low inhibitory concentrations (IC50) of $12.33 \pm 0.01 ; 12.86 \pm 0.04 ; 14.20 \pm 0.02$; $18.27 \pm 0.02$ and $18.28 \pm 0.02 \mathrm{mg} / \mathrm{mL}$, respectively, followed by extracts of $S . n i$ grum L2 $(21.83 \pm 0.1 \mathrm{mg} / \mathrm{mL})$ and $D$. liebrechtsiana De Wild $(23.06 \pm 0.01$ $\mathrm{mg} / \mathrm{mL}$ ), with not significant variations $(\mathrm{P}>0.05)$. While extracts of $S$. melongena, Amaranthus and B. campestris inhibit less free radicals with the strengths of IC50 of $28.28 \pm 0.08 ; 36.23 \pm 0.04$ and $42.08 \pm 0.34 \mathrm{mg} / \mathrm{mL}$, respectively, with not significant differences $(\mathrm{P}>0.05)$.

\subsection{Evaluation of the Antiradical Activity of the Different Extracts Fruit}

Figure 6 presents the results of the antiradical activity of the studied fruit. 


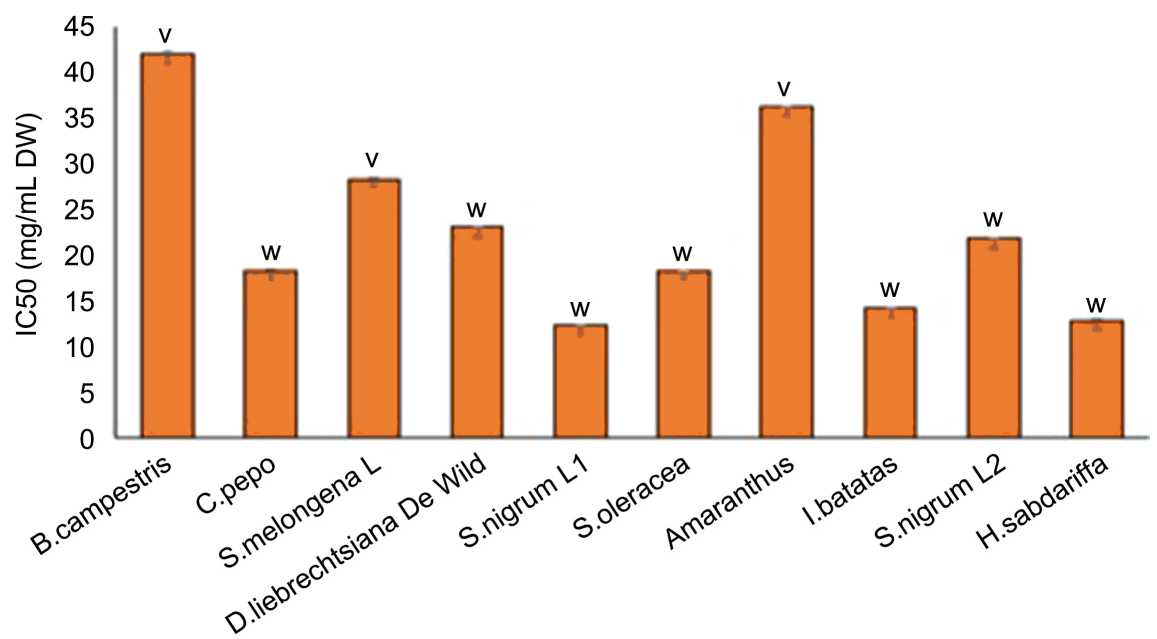

Figure 5. Inhibitory concentration 50 (IC50) of various vegetable extracts. When the letters above the bars are identical, the averages are identical (at the 5\% threshold). Otherwise, the averages are significantly different (at the $5 \%$ threshold).

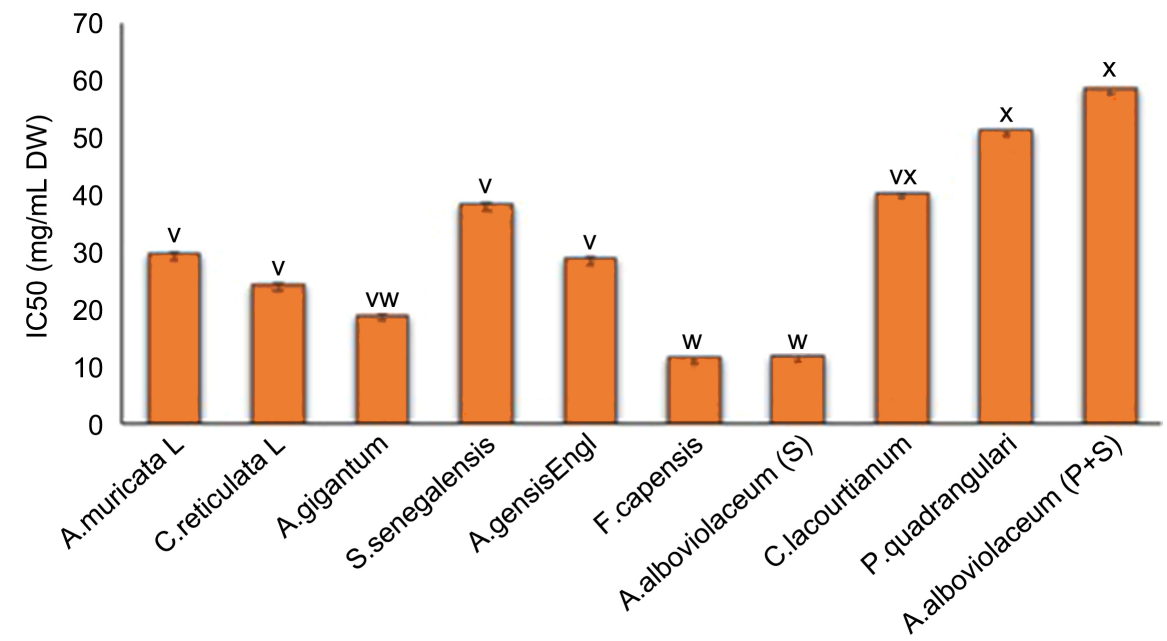

Figure 6. Inhibitory concentration 50 (IC50) of various fruit extracts. $\mathrm{S}=$ seeds, $\mathrm{P}=$ pulp. When the letters above the bars are identical, the averages are identical (at the $5 \%$ threshold). Otherwise, the averages are significantly different (at the $5 \%$ threshold).

It can be seen that extracts of $F$. capensis, $A$. alboviolaceum and $A$. gigantum strongly inhibit free radicals with respective IC50 of $11.47 \pm 0.07$ and $11.84 \pm 0.07$; $18.91 \pm 0.11 \mathrm{mg} / \mathrm{mL}$, followed by the extracts of $C$. reticulata $L(24.21 \pm 0.11$ $\mathrm{mg} / \mathrm{mL})$, A. gensisEngl $(28.90 \pm 0.21 \mathrm{mg} / \mathrm{mL})$ and $A$. muricata $L(29.76 \pm 0.20$ $\mathrm{mg} / \mathrm{mL}$ ). The lowest anti-radical activity was observed with extracts of $S$. senegalensis $(38.34 \pm 0.20 \mathrm{mg} / \mathrm{mL})$, C. lacourtianum $(40.03 \pm 0.03 \mathrm{mg} / \mathrm{mL})$, P. quadrangularis $(51.36 \pm 0.02 \mathrm{mg} / \mathrm{mL})$ and A. alboviolaceum $(58.68 \pm 0.08 \mathrm{mg} / \mathrm{mL})$.

The results of this study show that vegetables such as $S$. nigrum $L 1, H$. sabdariffa, I. batatas, S. oleracea and C. pepo, on the one hand, and fruit such as F. capensis, $A$. alboviolaceum and $A$. gigantum on the other hand, reduce free radicals better. This strong inhibition of free radicals could be justified by the relatively high concentrations of total polyphenols and flavonoids quantified in this 
study. Indeed, polyphenolic compounds are reputed to be powerful compounds with the ability to reduce free radicals [25]. The results obtained correlate clearly with the total polyphenol content and strongly advocate for the consumption of these fruit and vegetables as potential natural additives in the food instead of synthetic compounds [14] [25] [38] [39].

\section{Conclusion}

Our study aimed at valorizing the African plants in general, and in particular some varieties of fruit and vegetables consumed in Congo Brazzaville. Twenty species of edible fruit and vegetables were analyzed in order to quantify their polyphenol and flavonoids content, and their antiradical activity. The contents of total polyphenols and flavonoids were higher in vegetable extracts than in fruit ones. However, fruit such as the C. lacourtianum and of $A$. alboviolaceum also showed high contents of total polyphenols and flavonoids. Among the vegetables studied, C. pepo, I. batatas, H. sabdariffa and $S$. negrum 1 had high levels of total polyphenols and flavonoids. In addition, extracts of C. pepo, I. batatas, $H$. sabdariffa, $S$. negrum $1, F$. capensis and $A$. alboviolaceum also exhibited a substantial antiradical activity, justified by their considerable content in total polyphenols and flavonoids. Thus, these fruit and vegetables could not only be used to treat various health disorders, but also contribute significantly to the prevention of degenerative diseases. It would be important to extend the investigations by identifying the different phenolic compounds from vegetables and fruit that have shown both high phenolic compound contents and an important antiradical activity.

\section{Conflicts of Interest}

The authors declare no conflicts of interest regarding the publication of this paper.

\section{References}

[1] Leterme, P., Buldgen, A., Estrada, F. and Londoño, A.M. (2006) Mineral Content of Tropical Fruits and Unconventional Foods of the Andes and the Rain Forest of Colombia. Food Chemistry, 95, 644-652. https://doi.org/10.1016/j.foodchem.2005.02.003

[2] Ramful, D., Tarnus, E., Aruoma, O.I., Bourdon, E. and Bahorun, T. (2011) Polyphenol Composition, Vitamin C Content and Antioxidant Capacity of Mauritian Citrus Fruit Pulps. Food Research International, 44, 2088-2099. https://doi.org/10.1016/j.foodres.2011.03.056

[3] Lock, K., Pamerleau, J., Causer, L., Altmann, D.R. and McKee, M. (2005) The Global Burden of Disease Attributable to Low Consumption of Fruit and Vegetables: Implications for the Global Strategy on Diet. Bulletin of the World Health Organization, 83, 100-108.

[4] Pollard, C., Miller, M., Woodman, R.J., Meng, R. and Binns, C. (2009) Changes in Knowledge, Beliefs, and Behaviors Related to Fruit and Vegetable Consumption among Western Australian Adults from 1995 to 2004. American Journal of Public 
Health, 99, 355-361. https://doi.org/10.2105/AJPH.2007.131367

[5] Adjrah, Y., Karou, D.S., Djéri, B., Anani, K., Soncy, K., Ameyapoh, Y., De Souza, C. and Gbeassor, M. (2011) Hygienic Quality of Commonly Consumed Vegetables, and Perception about Disinfecting Agents in Lomé. International Food Research Journal, 18, 1499-1503.

[6] Bvenura, C. and Sivakumar, D. (2017) The Role of Wild Fruits and Vegetables in Delivering a Balanced and Healthy Diet. Food Research International, 99, 15-30. https://doi.org/10.1016/j.foodres.2017.06.046

[7] Lamien-Meda, A., Lamien, C.E., Compaoré Moussa, M.Y., Meda Roland, N.T., Kiendrebeogo, M., Zeba, B., Millogo, J.F and Nacoulma, O.G. (2008) Polyphenol Content and Antioxidant Activity of Fourteen Wild Edible Fruits from Burkina Faso. Molecules, 13, 581-594. https://doi.org/10.3390/molecules13030581

[8] Roberts, J.L. and Moreau, R. (2016) Functional Properties of Spinach (Spinacia oleracea L.) Phytochemicals and Bioactive. Food Function, 7, 3337-3353. https://doi.org/10.1039/C6FO00051G

[9] Scalbert, A., Manach, C., Morand, C., Remesy, C. and Jimenez, L. (2005) Dietary Polyphenols and the Prevention of Diseases. Critical Reviews in Food Science and Nutrition, 45, 287-306. https://doi.org/10.1080/1040869059096

[10] Amitabha, R. (2005) Cancer Selective Role of Selected Dietary Factors. India Journal of Cancer, 42, 15-24. https://doi.org/10.4103/0019-509X.15095

[11] John, J.A. and Shahidi, F. (2010) Phenolic Compounds and Antioxidant Activity of Brazil Nut (Bertholletia excelsa). Journal of Functional Foods, 2, 196-209. https://doi.org/10.1016/j.jff.2010.04.008

[12] Kaison, O., Siriamornpn, S., Weerapreeyakul, N. and Meeso, N. (2011) Phenolic Compounds and Antioxidant Activities of Edible Flowers from Thailand. Journal of Functional Foods, 3, 88-99. https://doi.org/10.1016/j.jff.2011.03.002

[13] Kaur, C. and Kapoor, H.C. (2001) Antioxidants in Fruits and Vegetables-The Millennium's Health. International Journal of Food Science \& Technology, 36, 703-725.

[14] Vijaya Kumar Reddy, C., Sreeramulu, D. and Raghunath, M. (2010) Antioxidant Activity of Fresh and Dry Fruits Commonly Consumed in India. Food Research International, 43, 285-288. https://doi.org/10.1016/j.foodres.2009.10.006

[15] Yadav, B.S., Yadav, R., Yadav, R.B. and Garg, M. (2016) Antioxidant Activity of Various Extracts of Selected Gourd Vegetables. Journal of Food Science \& Technology, 53, 1823-1833. https://doi.org/10.1007/s13197-015-1886-0

[16] Cho, M., Lee, H.-J., Kang, M.-H. and Min, H. (2017) Comparison of Antioxidant Activity and Prevention of Lymphocyte DNA Damage by Fruit and Vegetable Juices Marketed in Korea. Journal of Nutrition and Health, 50, 1-9. https://doi.org/10.4163/jnh.2017.50.1.1

[17] Block, G., Patterson, B. and Subar, A. (1992) Fruits, Vegetables and Cancer Prevention: A Review of the Epidemiological Evidence. Nutrition and Cancer, 18, 1-29. https://doi.org/10.1080/01635589209514201

[18] Rawat, S., Jugran, A., Giri, L., Bhatt, I.D. and Rawal, R.S. (2011) Assessment of Antioxidant Properties in Fruits of Myrica esculenta: A Popular Wild Edible Species in Indian Himalayan Region. Evidence-Based Complementary and Alternative Medicine, 2011, Article ID: 512787. https://doi.org/10.1093/ecam/neq055

[19] Amira, E.A., Behija, S.E., Beligh, M., Lamia, L., Manel, I., Mohamed, H. and Lotfi, A. (2012) Effects of the Ripening Stage on Phenolic Profile, Phytochemical Composition and Antioxidant Activity of Date Palm Fruit. Journal Agricultural and Food 
Chemistry, 60, 10896-10902. https://doi.org/10.1021/jf302602v

[20] Shan, S., Huang, X., Shah, M.H. and Abbasi, A.M. (2019) Evaluation of Polyphenolics Content and Antioxidant Activity in Edible Wild Fruits. BioMed Research International, 2019, Article ID: 1381989. https://doi.org/10.1155/2019/1381989

[21] Cherif, J.K., M’Rabet, I., El Habiri, M., Abidi, R. and Albrecht-Gary, A.-M. (2006) Mesure de l'activité antiradicalaire du jus et des peaux d'oranges tunisiennes par le radical DPPH. Fruits, 61, 99-107. https://doi.org/10.1051/fruits:2006008

[22] Ketsawatsukul, U., Whiteman, M. and Halliwell, B. (2000) A Reevaluation of the Peroxynitrite Scavenging Activity of Some Dietary Phenolics. Biochemical and Biophysical Research Communications, 279, 692-699. https://doi.org/10.1006/bbrc.2000.4014

[23] Pereira, J.A., Oliveira, I., Sousa, A., Valent, P., Andrade, P.B., Ferreira, I.C., Ferreres, F., Bento, A., Seabra, R. and Estevinho, L. (2007) Walnut (Juglans regia L.) Leaves: Phenolic Compounds, Antibacterial Activity and Antioxidant Potential of Different Cultivars. Food and Chemical Toxicology, 45, 2287-2295.

https://doi.org/10.1016/j.fct.2007.06.004

[24] Sarker, U. and Oba, S. (2018) Response of Nutrients, Minerals, Antioxidant Leaf Pigments, Vitamins, Polyphenol, Flavonoid and Antioxidant Activity in Selected Vegetable Amaranth under Four Soil Water Content. Food Chemistry, 252, 72-83. https://doi.org/10.1016/j.foodchem.2018.01.097

[25] Gouollaly, T., Andzi-Barhé, T., Makomo, H., Mboungou, B., Boumba, S., Makambila, M.C. and Ongoka, P.R. (2019) Radical Scavenging Capacity and Total Polyphenols Content of the Hydro-Ethanolic Extract and Fractions from Eugenia uniflora L. Journal of Pharmacognosy and Phytochemistry, 8, 305-309.

[26] Muanda, F., Koné, D., Dicko, A., Soulimani, R. and Younos, C. (2011) Phytochemical Composition and Antioxidant Capacity of Three Malian Medecinal Plant Parts. Evidence-Based Complementary and Alternative Medicine, 2011, Article ID: 674320. https://doi.org/10.1093/ecam/nep109

[27] Hennebelle, T. (2006) Investigation Chimique, chimiotaxonomique et pharmacologique de lamiale productrices d'antioxydants: Marrubuimperegrinum, ballota pseudodictamnus (Laminacées) et Lippia alba (Verbénacées). Thèse de doctorat, Université des Sciences et Technologies de Lille1, Lille.

[28] Ikram, E.H.K., Eng, K.H., Jalil, A.M.M., Ismail, A., Idris, S., Azlan, A., Nazri, H.S.M., Diton, N.A.M. and Mokhtar, R.A.M. (2009) Antioxidant Capacity and Total Phenolic Content of Malaysian Underutilized Fruits. Journal of Food Composition and Analysis, 22, 388-393. https://doi.org/10.1016/j.jfca.2009.04.001

[29] Ouchemoukh, S., Hachoud, S., Boudraham, H., Mokrani, A. and Louaileche, H. (2012) Antioxidant Activities of Some Dried Fruits Consumed in Algeria. Food Science and Technology, 49, 329-332. https://doi.org/10.1016/j.lwt.2012.07.022

[30] Benmeddour, Z., Mehinagic, E., LeMeurlay, D. and Louaileche, H. (2013) Phenolic Composition and Antioxidant Capacities of Ten Algerian Date (Phoenix dactylifera L.) Cultivars: A Comparative Study. Journal of Functional Foods, 5, 346-354. https://doi.org/10.1016/j.jff.2012.11.005

[31] Li, W., Gao, Y., Zhao, J. and Wang, Q. (2007) Phenolic, Flavonoid, and Lutein Ester Content and Antioxidant Activity of 11 Cultivars of Chinese Marigold. Journal of Agricultural and Food Chemistry, 55, 8478-8484. https://doi.org/10.1021/jf071696j

[32] Gyamfi, M.A. and Aniya, Y. (2002) Antioxidant Properties of Thonningianin A. Isolated from the African Medicinal Herb. Thonningia sanguinea. Biochemical Pharmacology, 63, 1725-1737. https://doi.org/10.1016/S0006-2952(02)00915-2 
[33] Shen, S.Q., Zhang, Y., Xiang, J.J. and Xiong, C.L. (2007) Protective Effect of Curcumin against Liver Warm Ischemia/Reperfusion Injury in Rat Model Is Associated with Regulation of Heat Shock Protein and Antioxidant Enzymes. World Journal of Gastroenterology, 13, 1953-1961.

[34] Han, X., Shen, T. and Lou, H. (2007) Dietary Polyphenols and Their Biological Significance. International Journal of Molecular Sciences, 8, 950-988.

https://doi.org/10.3390/i8090950

[35] Escarpa, A. and González, M.C. (2001) Approach to the Content of Total Extractable Phenolic Compounds from Different Food Samples by Comparison of Chromatographic and Spectrophotometric Methods. Analytica Chimica Acta, 427, 119-127. https://doi.org/10.1016/S0003-2670(00)01188-0

[36] Le Marchand, L. (2002) Cancer Preventive Effects of Favonoids-A Review. Biomedicine \& Pharmacotherapy, 56, 296-301. https://doi.org/10.1016/S0753-3322(02)00186-5

[37] Yao, L.H., Jiang, Y.M., Shi, J., Tomas-Barberan, F.A., Datta, N., Singanusong, R. and Chien, S.S. (2004) Flavonoids in Food and Their Health Benefits, Plant. Foods for Human Nutrition, 59, 113-122. https://doi.org/10.1007/s11130-004-0049-7

[38] Adelakun, O.E., Oyelade, O.J., Ade-Omowaye, B.I., Adeyemi, I.A. and Van De Venter, M. (2009) Chemical Composition and the Antioxidative Properties of Nigerian Okra Seed (Abelmoschus esculentus Moench) Flour. Journal Food and Chemical Toxicology, 47, 1123-1126. https://doi.org/10.1016/j.fct.2009.01.036

[39] Huang, A.G., Chen, X.H., Gao, Y.Z. and Che, J. (2007) Determination and Analysis of Ingredient in Okra. China Journal Food Sciences, 28, 451-455. 